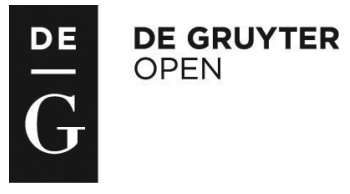

\title{
ASSOCIATIONS OF SIX SNPS OF POU1F1-PROP1-PITX1-SIX3 PATHWAY GENES WITH GROWTH TRAITS IN TWO CHINESE INDIGENOUS GOAT BREEDS
}

\author{
Lin $\mathrm{Ma}^{1 *}$, Qiaomei Qin²*, Qing Yang ${ }^{1}$, Meng Zhang ${ }^{1}$, Haiyu Zhao ${ }^{1}$, Chuanying Pan ${ }^{1}$, Chuzhao Lei', \\ Hong Chen ${ }^{1 *}$, Xianyong Lan ${ }^{1 *}$ \\ ${ }^{1}$ College of Animal Science and Technology, Northwest A\&F University, Shaanxi Key Laboratory \\ of Molecular Biology for Agriculture, Yangling, Shaanxi, 712100, China \\ ${ }^{2}$ Department of Pharmaceutical Science and Technology/Animal Science, Heze University, Heze, \\ Shandong, 274015, China \\ *These authors equally contributed to this work \\ •Corresponding authors: lanxianyong79@nwsuaf.edu.cn; chenhong1212@126.com
}

\begin{abstract}
In the process of anterior pituitary gland development and maturation, numerous transcription factors were involved in the pituitary organogenesis. To date, the lack of knowledge on POU1F1PROP1-PITX1-SIX3 pathway genes affecting growth traits was reported in Chinese goat breeds. The objective of this work was to identify genetic variants of the POU1F1, PROP1, PITX1 and SIX3 genes, as well as to evaluate their associations with growth traits in goats. The results showed that one novel and five reported single nucleotide polymorphisms (SNP) were confirmed in above four genes. The novel SNP (NC_019460.2:g.1100T $>$ A) was located in intron 1 of $S I X 3$ gene. Among these loci, DQ826397.1:g.102T>G (SNP1), DQ826397.1:g.279T>C (SNP2) and NC_019460.2:g.1100T>A (SNP6) were associated with growth traits. In details, the SNP1 locus had significant association with hucklebone width $(\mathrm{P}<0.05)$ and hucklebone width index $(\mathrm{P}<0.05)$ in the Guanzhong dairy goat. The SNP2 locus was associated with body weight $(\mathrm{P}<0.05)$, chest circumference $(\mathrm{P}<0.01)$, chest width $(\mathrm{P}<0.05)$, hucklebone width $(\mathrm{P}<0.05)$, cannon circumference $(\mathrm{P}<0.01)$ and trunk index $(\mathrm{P}<0.01)$ in the Hainan black goat. The SNP6 locus was significantly associated with hucklebone width index $(\mathrm{P}<0.05)$ and chest width $(\mathrm{P}<0.05)$ in the Guanzhong dairy goat and Hainan black goat, respectively. These findings indicated that goat POU1F1-PROP1-PITX1-SIX3 pathway genes were important genetic factors, which could affect growth traits. Three SNPs detected in this study may be useful for potential marker-assisted selection programs in goat breeding and production.
\end{abstract}

Keywords: goat, $P O U 1 F 1$ gene, $P R O P 1$ gene, $P I T X 1$ gene, $S I X 3$ gene, polymorphism, growth traits

\section{Abbreviations}

POU1F1: pituitary specific transcription factor 1; PROP1: prophet of PIT1; PITX1: paired-like homeodomain transcription factor 1; SIX3: SIX homeobox 3; $G H$ : growth hormone; $P R L$ : prolactin; $T S H$ : thyroid-stimulating hormone; $b p$ : base 
pair; $S N P$ : single nucleotide polymorphism; $P C R$ : polymerase chain reaction; $R F L P$ : restriction fragment length polymorphism; $\mathrm{Ho}$ : homozygosity; $\mathrm{He}$ : heterezygosity; $N e$ : effective allele numbers; PIC: polymorphism information content; HWE: HardyWeinberg equilibrium; $G Z$ : Guanzhong dairy goat; $H N B G$ : Hainan black goat; $B W$ : body weight; $B H$ : body height; $B L$ : body length; $B S L$ : body slanting length; $C h C$ : chest circumference; $C h D$ : chest depth; $C h W$ : chest width; $H u W$ : hucklebone width; $\mathrm{CaC}$ : cannon circumference; $T I$ : trunk index; $B L I$ : body length index; $C h C I$ : chest circumference index; $\mathrm{CaCI}$ : cannon circumference index; $C W I$ : chest width index; $H u W I$ : hucklebone width index; $C V$ : coefficient of variation.

Growth traits are important economic traits in breeding, genetics and reproduction for goat. In goat industry, it is difficult to obtain a big genetic progress using traditional breeding methods, however, application of marker-assisted selection (MAS) to improve these traits is shown to be an efficient strategy (Ahlawat et al., 2015; Pan et al., 2013; Zhao et al., 2013). As we know, goat growth traits are under the control of multiple genes which may be crucial for unraveling the association of genetic variations with growth traits (Jalil-Sarghale et al., 2014; Zhang et al., 2015). But limited studies on pathway genes affecting growth and development are available in goats. Therefore, it is critical to find out numerous candidate genes, which is also the initial and crucial step to quickly and efficiently establish a MAS system in goats breeding (Zhang et al., 2015).

In the process of development and maturation of the anterior pituitary gland, numerous transcription factors are involved in pituitary organogenesis, such as POU homeodomain family (e.g. POU1F1 and PROP1), PITX family (e.g. PITX1 and PITX2) and SIX family (e.g. SIX3 and SIX6) (Huai et al., 2011; Savage et al., 2003). Currently, POU1F1, PROP1, PITX1 and SIX3 genes belong to the same pathway genes: POU1F1-PROP1-PITX1-SIX3.

POU1F1 (also known as PIT-1 or GHF-1 previously) is a positive regulator for growth hormone $(\mathrm{GH})$, prolactin (PRL), thyroid stimulating hormone (TSH), and itself in mammals (Cohen et al., 1997; Ribeca et al., 2014). Therefore, mutations on this gene may result in deficiency of GH, PRL, TSH, and POU1F1 (Lan et al., 2009 b). In our current studies, several polymorphisms were found of POU1F1 gene, which were related to milk yield and body weight in goat and cattle (Lan et al., 2007 a, b; Zhang et al., 2009; Zhou et al., 2016). Recently, mutations of POU1F1 gene were reported to be associated with growth and meat quality traits in rabbit (Wang et al., 2015), sheep milk production traits (Mura et al., 2012; Ozmen et al., 2014), sheep weaning weight (Sadeghi et al., 2014), sheep growth and biometric traits (Jalil-Sarghale et al., 2014), milk production traits and litter size in goat (Daga et al., 2013; Feng et al., 2012), milk production in cow (Ahmadi et al., 2015), carcass weight in cattle (Seong et al., 2011), carcass characteristics in crossbred pigs (Kim et al., 2014) and chicken body weight and egg numbers (Yan et al., 2013).

As a paired class homeodomain transcription factor, PROP1 (also named prophet of POU1F1) is specifically expressed in the pituitary gland, and plays a direct or indirect crucial role in the ontogenesis of pituitary gonadotropes, somatotropes, lactotropes and caudomedial thyrotropes (Lan et al., 2009 a). PROP1 mutations have been found to be associated with litter size and wool traits in sheep (Liu et al., 2015; 
Zeng et al., 2011), growth traits in cattle (Pan et al., 2013) and secretion of pituitary hormones in human (Baş et al., 2015; Lazea et al., 2015).

Paired-like homeodomain transcription factor 1 (PITX1) plays an important role in pituitary development by indirectly regulating the expression of the $G H$ and $P R L$ genes (Poulin et al., 2000). Therefore, PITX1 gene is regarded as a potential candidate gene for building the relationship between the gene polymorphisms and growth traits (Poulin et al., 2000). PITX1 gene mutations have been found to be associated with milk performance in dairy goats (Lan et al., 2013).

SIX homeobox 3 (SIX3) gene is responsible for normal mammalian pituitary development, and its genetic variations or deficiency will cause hypopituitarism, suggesting that this gene is a potential candidate gene for studying association with growth traits in animals (Lan et al., 2011). SIX3 gene mutations have been found to be associated with growth traits in cattle (Lan et al., 2011).

Considering POU1F1-PROP1-PITX1-SIX3 pathway genes contribute greatly to growth traits in livestock, it is important to explore the genetic variants of these genes. Our purpose of this study was to identify single nucleotide polymorphisms (SNPs) in above-mentioned genes and carry out their association analysis with growth traits. The results of this study could provide useful genetic markers for animal dairy goats selection and breeding through MAS.

\section{Material and methods}

All animal experiments were implemented following relevant laws and institutional guidelines and were approved by Northwest A\&F University Institutional Animal Care and Use Committee.

\section{Animals and data collection}

In this study, a total of 519 goats from two well-known Chinese native goat breeds (Guanzhong dairy goat (GZ), $n=235$; Hainan black goat (HNBG), $n=284$ ) were used. All selected individuals were healthy and unrelated (Zhao et al., 2013). All GZ individuals were 2 to 4 years old. The GZ goats were reared on the Sanyuan dairy goat breeding farm in Sanyuan county, Shaanxi, P.R. China (Zhao et al., 2013). The HNBG goats were 2 to 3 years old and reared in native breeding farms, in Zanzhou County, Hainan province, China (Zhang et al., 2015). All goats were allowed access to feed ad libitum using standard feeding and management protocols.

Body measurement traits for all selected individuals were measured, including body weight $(\mathrm{BW})$, body height $(\mathrm{BH})$, body length $(\mathrm{BL})$, body slanting length (BSL), chest circumference (ChC), chest depth (ChD), chest width $(\mathrm{ChW})$, hucklebone width $(\mathrm{HuW})$, cannon circumference $(\mathrm{CaC})$. Consequently, trunk index (TI), body length index (BLI), chest circumference index (ChCI), cannon circumference index (CaCI), chest width index (CWI) and hucklebone width index (HuWI), were also calculated on the basis of our reported description (Fang et al., 2010; Xu et al., 2010). The number of records and means, maximum, minimum and coefficient of variation $(\mathrm{CV})$ for the analyzed traits are shown in Table 1. 
Table 1. Statistics information of the phenotypic traits of GZ and HNBG breeds

\begin{tabular}{l|c|c|c|c|c|c|c|c|c|c}
\hline \multirow{2}{*}{ Traits } & \multicolumn{9}{c|}{ GZ } & \multicolumn{6}{c}{ HNBG } \\
\cline { 2 - 12 } & mean & SD & max & min & CV & mean & SD & max & min & CV \\
\hline BW (kg) & - & - & - & - & - & 28.28 & 7.01 & 51.00 & 13.50 & 0.25 \\
BH (cm) & 68.48 & 3.47 & 75.70 & 60.00 & 0.05 & 52.63 & 4.15 & 64.70 & 40.10 & 0.08 \\
BL (cm) & 76.56 & 5.23 & 89.40 & 62.80 & 0.07 & - & - & - & - & - \\
BSL (cm) & - & - & - & - & - & 55.86 & 7.01 & 68.30 & 13.50 & 0.25 \\
ChC (cm) & 89.02 & 4.26 & 98.20 & 80.20 & 0.05 & 71.98 & 4.15 & 91.00 & 40.10 & 0.08 \\
ChD (cm) & - & - & - & - & - & 26.42 & 4.51 & 33.00 & 43.80 & 0.08 \\
ChW (cm) & 28.13 & 2.72 & 34.00 & 22.00 & 0.10 & 14.81 & 6.50 & 21.60 & 54.00 & 0.09 \\
HuW (cm) & 23.24 & 3.33 & 30.00 & 16.20 & 0.14 & 13.65 & 2.38 & 17.20 & 14.50 & 0.09 \\
CaC (cm) & 10.82 & 1.30 & 14.10 & 6.60 & 0.12 & 7.78 & 1.88 & 10.00 & 10.80 & 0.13 \\
TI (\%) & 116.62 & 7.56 & 137.74 & 101.74 & 0.06 & 129.06 & 1.37 & 173.91 & 9.00 & 0.10 \\
BLI (\%) & 111.90 & 7.03 & 129.30 & 96.91 & 0.06 & 106.41 & 0.73 & 130.42 & 6.00 & 0.09 \\
ChCI (\%) & 130.23 & 7.97 & 154.88 & 117.44 & 0.06 & 136.99 & 9.04 & 167.08 & 105.88 & 0.07 \\
CaCI (\%) & 15.85 & 2.15 & 21.02 & 9.78 & 0.14 & 14.82 & 8.05 & 19.27 & 83.15 & 0.08 \\
CWI (\%) & - & - & - & - & - & 56.19 & 10.14 & 77.24 & 105.82 & 0.07 \\
HuWI (\%) & 123.54 & 22.22 & 177.33 & 85.71 & 0.18 & 108.85 & 1.32 & 145.22 & 11.08 & 0.09 \\
\hline
\end{tabular}

\section{DNA isolation and DNA pool construction}

The genomic DNA samples were isolated from the ear tissues and the leukocytes of the blood sample according to the procedure described by Lan et al. (2007 b). Based on our previous report (Lan et al., 2013), all genomic DNA samples were diluted to the identical concentration $(50 \mathrm{ng} / \mu \mathrm{L})$ for the DNA pool construction or the PCR amplification. A total of fifty DNA samples were randomly selected from the GZ and HNBG breeds to construct two different genomic DNA pools, respectively. The genomic DNA pools were used as templates for PCR amplification and exploring genetic variation in POU1F1, PROP1, PITX1 and SIX3 genes.

\section{Primers design, PCR amplification and DNA sequencing}

In our previous study (Lan et al., 2007 a, b; Lan et al., 2009 a, b; Lan et al., 2013), we found five SNPs in POU1F1-PROP1-PITX1-SIX3 pathway genes, namely, DQ826397.1:g.102T $>$ G (SNP1), DQ826397.1:g.279T $>$ C (SNP2), DQ826397.1:g.365T >C (SNP3), AF453512:g.1795C $>$ T (SNP4), NW_00314033:g.201G>A (SNP5). These SNPs could be recognized by the DdeI, AluI, PstI, Hin6I and MspI (MBI Fermentas, Vilnius, Lithuania) restriction endonuclease, respectively. Based on that, three pairs of primers P1, P2 and P3 were synthesized to test the polymorphisms of the goat POU1F1 gene, PROP1 gene and PITX1 gene, respectively (Table 2).

As the caprine $S I X 3$ gene sequence was not published currently on NCBI, in this study, a total of four pairs of primers were designed to scan novel genetic variants in the caprine $S I X 3$ gene based on the ovine SIX3 gene sequence (GenBank Accession No. NC_019460.2) (Table 2).

The $20 \mu \mathrm{L}$ PCR volume included the $40 \mathrm{ng}$ genomic DNA, $0.4 \mu \mathrm{M}$ of each primer, $1 \times$ buffer (including $1.5 \mathrm{mM} \mathrm{MgCl}$ ), $160 \mu \mathrm{M}$ dNTPs (dATP, dTTP, dGTP and $\mathrm{dCTP}$ ), and 0.5 units of Taq DNA polymerase (MBI Fermentas, Vilnius, Lithuania). 
The cycling protocol was $95^{\circ} \mathrm{C}$ for $5 \mathrm{~min}, 35$ cycles of denaturing at $94^{\circ} \mathrm{C}$ for $30-50$ $\mathrm{s}$, annealing for $30-60 \mathrm{~s}$, extending at $72^{\circ} \mathrm{C}$ for $35 \mathrm{~s}$, with a final extension at $72^{\circ} \mathrm{C}$ for $10 \mathrm{~min}$ (Table 2).

Table 2. Primers used for detecting SNPs of the goat POU1F1-PROP1-PITX1-SIX3 pathway genes

\begin{tabular}{|c|c|c|c|c|c|}
\hline Primer name & Primer sequences $\left(5^{\prime}-3^{\prime}\right)$ & $\left|\begin{array}{c}\text { Product } \\
\text { size } \\
\text { (bp) }\end{array}\right|$ & $\begin{array}{c}T_{m} \\
\left({ }^{\circ} \mathrm{C}\right)\end{array}$ & Target region & Note \\
\hline $\begin{array}{l}\text { SNP1, SNP2 } \\
\text { and SNP3 (P1) } \\
\text { (POU1F1) }\end{array}$ & $\begin{array}{l}\text { F: CCATCATCTCCCTTCTT } \\
\text { R: AATGTACAATGTGCCTTCTGAG }\end{array}$ & 450 & 54.5 & $\begin{array}{l}\text { Exon 6, } \\
\text { partial intron } \\
5,3^{\prime} \text { UTR }\end{array}$ & $\begin{array}{l}\text { Cited from } \\
\text { Lan et al., } \\
2007 \text { a }\end{array}$ \\
\hline $\begin{array}{l}\text { SNP4 (P2) } \\
\text { (PROP1) }\end{array}$ & $\begin{array}{l}\text { F: ATGTGGTCTGGGATGGATG } \\
\text { R: CTGGTGAAGGTTTGGGTTAG }\end{array}$ & 414 & 54.3 & $\begin{array}{l}\text { Exon 2, } \\
\text { flanking } \\
\text { region }\end{array}$ & $\begin{array}{l}\text { Cited from } \\
\text { Lan et al., } \\
2009 \text { a }\end{array}$ \\
\hline $\begin{array}{l}\text { SNP5 (P3) } \\
\text { (PITX1) }\end{array}$ & $\begin{array}{l}\text { F: CCGCCTTCCACCTAGCCCGCAC } \\
\text { R: TCGTCCATGTCCACGTTCATCG }\end{array}$ & 230 & 65.2 & Intron 1 & $\begin{array}{l}\text { Cited from } \\
\text { Lan et al., } \\
2013\end{array}$ \\
\hline $\begin{array}{l}\text { SIX3-SNPs } \\
\text { scanning (P4) }\end{array}$ & $\begin{array}{l}\text { F: CGCCGATTCTCACCACC } \\
\text { R: AGGCTCCCAAGGACACGAC }\end{array}$ & 933 & 58.4 & $\begin{array}{l}\text { Exon } 1 \text { and } \\
\text { Intron } 1\end{array}$ & This study \\
\hline $\begin{array}{l}\text { SIX3-SNPs } \\
\text { scanning (P5) }\end{array}$ & $\begin{array}{l}\text { F: AGGCTTGAGCGGACAGGA } \\
\text { R: TCCAAGGGCATGGGTGAG }\end{array}$ & 914 & 59.0 & $\begin{array}{l}\text { Exon } 1 \text { and } \\
\text { Intron } 1\end{array}$ & This study \\
\hline $\begin{array}{l}\text { SIX3-SNPs } \\
\text { scanning (P6) }\end{array}$ & $\begin{array}{l}\text { F: CCTGAACCTTTGGCCCTCT } \\
\text { R: CTGACTCCGCTGTCTACGC }\end{array}$ & 701 & 57.0 & Intron 1 & This study \\
\hline $\begin{array}{l}\text { SIX3-SNPs } \\
\text { scanning (P7) }\end{array}$ & $\begin{array}{l}\text { F: GGGATCTGTCTGCTCCAGGGAC } \\
\text { R: AGGCTCGACACGCTGGTGGT }\end{array}$ & 520 & 64.8 & $\begin{array}{l}\text { Intron } 1 \text { and } \\
\text { Exon } 2\end{array}$ & This study \\
\hline $\begin{array}{l}\text { SIX3 } \\
\text { PCR-RFLP (P8) }\end{array}$ & $\begin{array}{l}\text { F: AGAAGGGCGAGCGTGAACAT } \\
\text { R: TGGATTCCTCCCAGGGTTTT }\end{array}$ & 264 & 56.0 & Intron 1 & This study \\
\hline
\end{tabular}

The framed base $\mathrm{A}$ at the P8-forward primer showed a mismatch for creating restriction sites (NdeI, CATATG), where the actual nucleotide was "G" at NC_019460.2:g.1100 locus.

To identify mutations within SIX3 gene of two goat breeds, DNA pool sequencing was carried out using the ABI 3730 sequencer (ABI, Foster City, CA, USA) in the forward and reverse directions.

\section{Genotyping of the SNPs within the goat POU1F1-PROP1-PITX1-SIX3 path- way genes}

Aliquots of $20 \mu \mathrm{L}$ PCR products of POU1F1 gene were digested with $10 \mathrm{U}$ DdeI, $A l u \mathrm{I}$, and PstI, for $5 \mathrm{~h}$ at $37^{\circ} \mathrm{C}$ following the supplier's directions, similarly, PCR products of PROP1 and PITX1 genes were digested with $10 \mathrm{U}$ Hin6I and MspI, respectively. The digested products were detected by electrophoresis in 2.0-3.0\% agarose gel stained with ethidium bromide (Lan et al., 2007 a, b; Lan et al., 2009 a, b; Lan et al., 2013).

SIX3 gene: Because the NC_019460.2:g.1100T>A (SNP6) could not be recognized by the natural restriction endonuclease, another pair of primer was designed 
to establish the NdeI Forced-PCR-RFLP, where the actual nucleotide "G" was induced into "A" at NC_019460.2:g.1098 locus. Thus, this introduced that point mutation would create an NdeI restriction site (CATATG) in the PCR products from the g.1100A goat carrier, whereas the PCR products from the g.1100T goat carrier lacked this restriction endonuclease site. In the NdeI PCR-RFLP analysis, the $20 \mu \mathrm{L}$ PCR products were digested with $5 \mathrm{U}$ NdeI (MBI Fermentas, Vilnius, Lithuania) for $12 \mathrm{~h}$ at $37^{\circ} \mathrm{C}$ following the manufacturer's protocol. All digested products were detected by electrophoresis in 3.5\% agarose gel stained with ethidium bromide.

\section{Statistical analysis}

Genotypic and allelic frequencies were determined through a direct count. Hardy-Weinberg equilibrium (HWE) was analyzed based on a predetermined value of the test statistic (Emigh, 1980). According to Nei's method (Nei and Roychoudhury, 1974), population parameters, including gene homozygosity (Ho), gene heterozygosity $(\mathrm{He})$, effective allele numbers $(\mathrm{Ne})$ and polymorphism information content (PIC), were performed by PopGene version 3.2 (Wang et al., 2013). Distribution differences for genotypic and allelic frequencies between different breeds were analyzed using the $\chi^{2}$ test. The associations between genotypes and growth traits of goat were analyzed by ANOVA using the statistical software SPSS (Version 22.0).

\section{Results}

Genetic variation, genotypic and allelic frequencies and genetic diversity of POU1F1-PROP1-PITX1-SIX3 pathway genes

The frequencies of genotype and allele of POU1F1-PROP1-PITX1-SIX3 pathway genes were calculated in the GZ and HNBG breeds. The results were summarized in Table 3.

The present results confirmed the previous findings. For POU1F1 gene, the $450 \mathrm{bp}$ products were amplified using the specific combination of primers, the digestion with $A l u \mathrm{I}, D d e \mathrm{I}$ and PstI. For PROPI gene, the amplified PCR fragments (414 bp) were digested by Hin6I endonuclease (Xu et al., 2010). A genetic variant (NW_00314033: g.201G>A, SNP5) was identified at PITX1 gene. This SNP is located at nt41 position of the first intron, which can be genotyped by the MspI PCRRFLP.

SIX3 gene: The pool sequencing and alignment analysis identified one novel SNP at intron 1 within SIX3 gene (NC_019460.2:g.1100T>A) in GZ and HNBG breeds (Figure $1 \mathrm{a}$ ). The SNP could be genotyped by the NdeI PCR-RFLP method. At the NdeI locus, the allele " $\mathrm{T}$ " demonstrated one band (264 bp), while the allele "A" demonstrated two bands (244 bp and $20 \mathrm{bp}$ ). Accordingly, genotype TT showed only one band (264 bp) and genotype CC showed two bands (244 bp and $20 \mathrm{bp}$ ); while genotype TC showed three bands (264 bp, 244 bp and 20 bp) (Figure 1 b). It was obvious that $264 \mathrm{bp}$ and $244 \mathrm{bp}$ fragments could clearly classify the genotypes. 
Table 3. Genotypes, allele and HWE for the SNPs within the goat POU1F1-PROP1-PITX1-SIX3 pathway genes in GZ and HNBG breeds

\begin{tabular}{|c|c|c|c|c|c|c|c|}
\hline Loci/breed & Sizes & \multicolumn{3}{|c|}{ Genotype frequencies } & \multicolumn{2}{|c|}{ Allele frequencies } & HWE \\
\hline SNP1 & $\mathrm{N}$ & TT & TG & GG & $\mathrm{T}$ & $\mathrm{G}$ & P-values \\
\hline GZ & 235 & 0.022 & 0.281 & 0.697 & 0.163 & 0.837 & $\mathrm{P}>0.05$ \\
\hline HNBG & 284 & 0.294 & 0.452 & 0.254 & 0.520 & 0.480 & $\mathrm{P}>0.05$ \\
\hline SNP2 & $\mathrm{N}$ & TT & $\mathrm{TC}$ & $\mathrm{CC}$ & $\mathrm{T}$ & $\mathrm{C}$ & P-values \\
\hline GZ & 235 & 0.963 & 0.037 & 0.000 & 0.981 & 0.019 & $\mathrm{P}>0.05$ \\
\hline HNBG & 284 & 0.544 & 0.266 & 0.190 & 0.677 & 0.323 & $\mathrm{P}<0.01$ \\
\hline SNP3 & $\mathrm{N}$ & TT & $\mathrm{TC}$ & $\mathrm{CC}$ & $\mathrm{T}$ & $\mathrm{C}$ & P-values \\
\hline GZ & 235 & 0.549 & 0.440 & 0.011 & 0.769 & 0.231 & $\mathrm{P}<0.05$ \\
\hline HNBG & 284 & 0.965 & 0.035 & 0.000 & 0.983 & 0.017 & $\mathrm{P}>0.05$ \\
\hline SNP4* & $\mathrm{N}$ & TT & $\mathrm{TC}$ & $\mathrm{CC}$ & $\mathrm{T}$ & $\mathrm{C}$ & P-values \\
\hline GZ & 235 & 0.000 & 0.014 & 0.986 & 0.007 & 0.993 & $\mathrm{P}>0.05$ \\
\hline $\mathrm{HNBG}^{*}$ & 284 & 0.194 & 0.493 & 0.313 & 0.440 & 0.560 & $\mathrm{P}>0.05$ \\
\hline SNP5 & $\mathrm{N}$ & AA & AG & GG & A & $\mathrm{G}$ & P-values \\
\hline GZ & 235 & 0.224 & 0.118 & 0.658 & 0.283 & 0.717 & $\mathrm{P}<0.01$ \\
\hline HNBG & 284 & 0.906 & 0.067 & 0.027 & 0.940 & 0.060 & $\mathrm{P}<0.01$ \\
\hline SNP6 & $\mathrm{N}$ & AA & AT & TT & A & $\mathrm{T}$ & P-values \\
\hline GZ & 235 & 0.025 & 0.525 & 0.450 & 0.287 & 0.713 & $\mathrm{P}<0.05$ \\
\hline HNBG & 284 & 0.091 & 0.497 & 0.412 & 0.340 & 0.660 & $\mathrm{P}>0.05$ \\
\hline
\end{tabular}

At SNP4 locus, the genotype frequencies of TT $(\mathrm{P}=0.194), \mathrm{TC}(\mathrm{P}=0.493), \mathrm{CC}(\mathrm{P}=0.313)$, allele frequencies of T $(\mathrm{P}=0.440), \mathrm{C}(\mathrm{P}=0.560)$ and HWE $(\mathrm{P}>0.05)$ in HNBG breed were cited from Xu et al. (2010).
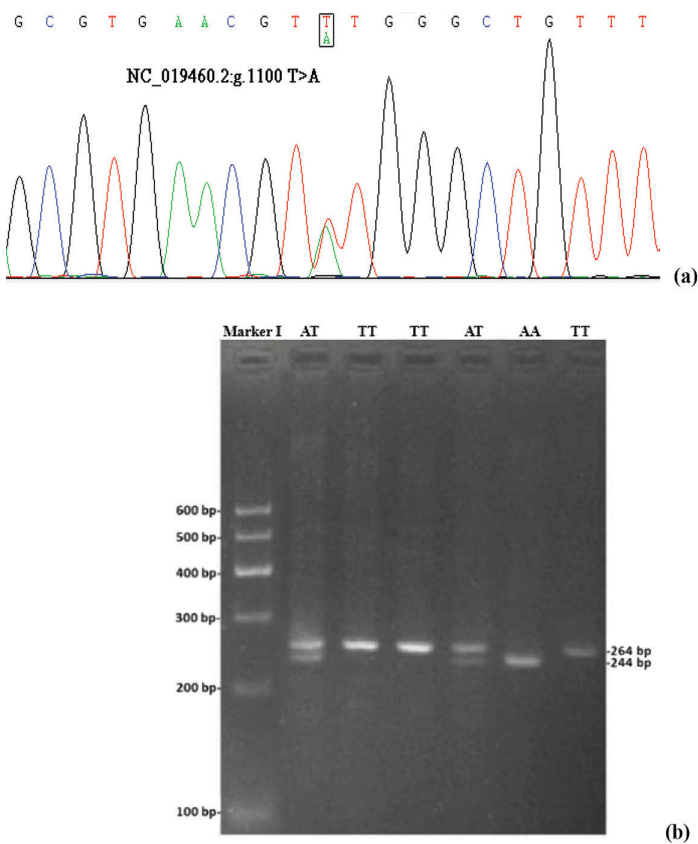

(a)

(b)

Figure 1. Sequencing results of mutation in the SIX3 gene (a). Electrophoresis pattern of the novel genetic variation of goat SIX3 gene (b) 
Genetic indices (Ho, He, Ne, and PIC) in the GZ and HNBG breeds were presented in Table 4. The values of Ho exceeded 0.500 at current SNPs. The values of Ne were approaching 2.000. The maximum and minimum PIC values were 0.375 and 0.013 . The $\chi^{2}$ test showed that the GZ breed was not at Hardy-Weinberg equilibrium in SNP3, SNP5 and SNP6 loci $(\mathrm{P}<0.05)$, the HNBG breed was not at Hardy-Weinberg equilibrium only in SNP2 and SNP5 loci $(\mathrm{P}<0.05)$ (Table 3).

Table 4. Ho, He, Ne and PIC for the SNPs within the POU1F1-PROP1-PITX1-SIX3 pathway genes in GZ and HNBG goat

\begin{tabular}{lll|c|c|c|c}
\hline \multicolumn{1}{c|}{ Loci } & \multicolumn{1}{c|}{ Breed } & Ho & He & Ne & PIC \\
\hline SNP1 & GZ & 0.727 & 0.273 & 1.375 & 0.236 \\
& HNBG & 0.501 & 0.499 & 1.997 & 0.375 \\
SNP2 & GZ & 0.964 & 0.036 & 1.038 & 0.036 \\
& HNBG & 0.563 & 0.437 & 1.777 & 0.342 \\
SNP3 & GZ & 0.645 & 0.355 & 1.551 & 0.292 \\
& HNBG & 0.966 & 0.034 & 1.035 & 0.034 \\
SNP4* & GZ & 0.987 & 0.013 & 1.014 & 0.013 \\
& HNBG* & 0.507 & 0.493 & 1.972 & 0.371 \\
SNP5 & GZ & 0.594 & 0.406 & 1.683 & 0.323 \\
& HNBG & 0.886 & 0.114 & 1.129 & 0.108 \\
SNP6 & GZ & 0.590 & 0.410 & 1.694 & 0.326 \\
& HNBG & 0.551 & 0.449 & 1.814 & 0.348 \\
\hline
\end{tabular}

At SNP4 locus, the Ho $(\mathrm{Ho}=0.507), \mathrm{He}(\mathrm{He}=0.493), \mathrm{Ne}(\mathrm{Ne}=1.972), \mathrm{PIC}(\mathrm{PIC}=0.371)$ in HNBG breed were cited from Xu et al. (2010).

\section{Association between genetic variations of POU1F1-PROP1-PITX1-SIX3 pathway genes and growth performance}

Statistical analysis revealed that only the four SNPs showed significant associations with growth traits (Tables 5, 6). At the SNP1 locus, different genotypes in the GZ breed were found to significantly associate with $\mathrm{HuW}$ and $\mathrm{HuWI}(\mathrm{P}<0.05)$. Individuals with genotype $\mathrm{TG}$ and $\mathrm{GG}$ demonstrated significantly inferior $\mathrm{HuW}$ when compared with the genotype TT. Genotype TT had significantly higher HuWI than those genotypes TG and GG. The TT homozygotes at the SNP2 locus had significantly higher $\mathrm{BW}, \mathrm{ChC}, \mathrm{ChW}, \mathrm{HuW}, \mathrm{CaC}$ and $\mathrm{TI}$ than genotypes TC $(\mathrm{P}<0.05)$ in HNBG breed. According to our previous report (Xu et al., 2010), at the SNP4 locus, the HNBG breed with genotype $\mathrm{CC}$ had significantly lower ChW, CWI and HuWI than those genotypes TT and TC $(\mathrm{P}<0.05)$. The AA at SNP6 locus had a lower ChW than TT and AT in the GZ goat breed. Moreover, the different genotypes in the HNBG breed were found to be significantly associated with CWI. 
Table 5. Associations of the SNP1 and SNP2 within POU1F1 gene and growth traits in GZ and HNBG goat $\left(\mathrm{LSM}^{\mathrm{a}} \pm \mathrm{SD}\right)$

\begin{tabular}{c|c|c|c|c|c}
\hline Loci/breed & Traits & TT & TG & GG & P-values \\
\hline SNP1/GZ & HuW (cm) & $17.35 \pm 0.21 \mathrm{~b}$ & $22.83 \pm 3.61 \mathrm{a}$ & $23.44 \pm 2.95 \mathrm{a}$ & $\mathrm{P}<0.05$ \\
& HuWI (\%) & $166.09 \pm 15.89 \mathrm{a}$ & $122.24 \pm 19.60 \mathrm{~b}$ & $124.34 \pm 20.98 \mathrm{~b}$ & $\mathrm{P}<0.05$ \\
Loci/breed & Traits & TT & TC & CC & P-values \\
SNP2/HNBG & BW (kg) & $29.11 \pm 6.24 \mathrm{a}$ & $26.31 \pm 7.05 \mathrm{~b}$ & $28.37 \pm 7.86 \mathrm{ab}$ & $\mathrm{P}<0.05$ \\
& ChC (cm) & $72.95 \pm 6.00 \mathrm{a}$ & $70.04 \pm 6.30 \mathrm{~b}$ & $71.48 \pm 7.36 \mathrm{ab}$ & $\mathrm{P}<0.01$ \\
& ChW (cm) & $15.06 \pm 1.73 \mathrm{a}$ & $14.30 \pm 1.95 \mathrm{~b}$ & $14.86 \pm 2.13 \mathrm{ab}$ & $\mathrm{P}<0.05$ \\
& HuW (cm) & $13.84 \pm 1.19 \mathrm{a}$ & $13.30 \pm 1.36 \mathrm{~b}$ & $13.62 \pm 1.50 \mathrm{ab}$ & $\mathrm{P}<0.05$ \\
CaC (cm) & $7.96 \pm 0.64 \mathrm{a}$ & $7.49 \pm 0.73 \mathrm{~b}$ & $7.67 \pm 0.75 \mathrm{~b}$ & $\mathrm{P}<0.01$ \\
& TI $(\%)$ & $130.75 \pm 10.02 \mathrm{a}$ & $126.40 \pm 9.62 \mathrm{~b}$ & $128.06 \pm 6.03 \mathrm{ab}$ & $\mathrm{P}<0.01$ \\
\hline
\end{tabular}

$\mathrm{a}, \mathrm{b}-$ values in rows with different letters differ significantly $(\mathrm{P} \leq 0.05)$.

Table 6. Associations of the SNP6 with growth traits in GZ and HNBG goat (LSM \pm SD)

\begin{tabular}{l|l|c|c|c|c}
\hline \multicolumn{1}{c}{ Breed } & Traits & AA & AT & TT & P-values \\
\hline GZ & ChW $(\mathrm{cm})$ & $24.70 \pm 3.25 \mathrm{~b}$ & $28.42 \pm 2.33 \mathrm{a}$ & $28.07 \pm 2.58 \mathrm{a}$ & $\mathrm{P}<0.05$ \\
HNBG & CWI $(\%)$ & $53.59 \pm 5.16 \mathrm{~b}$ & $56.92 \pm 5.87 \mathrm{a}$ & $57.94 \pm 5.37 \mathrm{a}$ & $\mathrm{P}<0.05$ \\
\hline
\end{tabular}

$\mathrm{a}, \mathrm{b}$ - values in rows with different letters differ significantly $(\mathrm{P} \leq 0.05)$.

\section{Discussion}

In this study, POU1F1-PROP1-PITX1-SIX3 pathway genes polymorphisms and their associations with growth performance were detected. A novel SNP (NC_019460.2:g.1100T $>$ A, named SNP6) within SIX3 gene was identified in intron 1. Although the intronic genetic variants do not change amino acids, many papers still have powerfully proved that intronic polymorphisms are significantly associated with quantitative traits varied from human to animals (Chang et al., 2015; Clark et al., 2015; Maitra et al., 2014; Palagano et al., 2015; Sun et al., 2015; Wang et al., 2015; Zhao et al., 2013; Zhou et al., 2016). For SNP6 locus, goats with genotype TT or AT had superior ChW and CWI compared to those with genotype AA in GZ and HNBG breeds, respectively. SIX3 gene played a critical role in affecting goat growth traits from the above mentioned description. Although mutation was detected at intron 1 region, the mutation might be linked to another mutation in the coding or regulatory regions of the gene, which was responsible for the growth performance (Lan et al., 2011).

The result revealed significant relationships between the SNP1 and HuW, HuWI in $\mathrm{GZ}$ breed, SNP2 and BW, ChC, ChW, HuW, CaC and TI in HNBG breed, suggesting that the $P O U 1 F 1$ gene had significant effects on growth traits. Overall, in HNBG breed, goats with genotype TT or CC had superior growth traits compared to those with genotype TC at SNP2 locus. The SNP1 and SNP2 were identified silent allele. For POU1F1 gene, although silent mutation did not change amino acid sequence, it possibly resulted in the change of Serine synonymous codon usage frequency. It 
could have an indirect effect on goat growth traits (Lan et al., 2007 a, b). The SNP4 locus of the other related gene $P R O P 1$ has been found to be associated with growth traits (Xu et al., 2010). During pituitary development, several critical transcription factors involved in POU1F1, PROP1, PITX1, SIX3, have their own temporal and spatial expression, and play key roles in affecting growth and development by affecting functional hormones, such as, GH, PRL and TSH $\beta$ (Castinetti et al., 2011; Pfäffle and Klammt, 2011; Savage et al., 2003). Therefore, pituitary transcription factors are responsible for a phenotype of combined pituitary hormone deficiency involving in $\mathrm{GH}, \mathrm{PRL}$ and TSH $\beta$, which indicates that these genes are associated with growth traits in livestock (Li et al., 1990). Taken together, POU1F1-PROP1-PITX1-SIX3 pathway genes are critical for selection and breeding in goat growth performance.

The associations of the goat POU1F1-PROP1-PITX1-SIX3 pathway genes polymorphisms and growth traits exhibited that these genes can be regarded as genetic marker genes correlating with growth traits. Therefore, these primary findings about the significant relationships between SNPs of the POU1F1-PROP1-PITX1-SIX3 pathway genes and growth traits will potentially contribute to the goat industry and these genes were given as critical candidate genes for selection and breeding in goat growth performance through MAS.

Besides, almost all of PIC values at the above polymorphic loci are more than 0.250, except SNP1, SNP2, SNP4 loci in GZ breed, SNP3 and SNP5 loci in HNBG breed, implying that these five loci possess low genetic diversity in GZ or HNBG breed. Therefore, these loci are not suggested to be effective in evaluating genetic resources of goat industry. The GZ and HNBG breeds were not at Hardy-Weinberg equilibrium in some loci $(\mathrm{P}<0.05)$. Genetically, it was possibly due to limited sample sizes or artificial selection, which complied with the background of GZ and HNBG culture. Of course, the genetic drift function and migration also might account for its disequilibrium.

To summarize, six SNPs extended the spectrum of genetic variation of the goat POU1F1-PROP1-PITX1-SIX3 pathway genes, and their significant association with growth performance would contribute to implementing MAS in breeding and genetics in goats.

\section{Conclusion}

In conclusion, a novel SNP extended the spectrum of genetic variation of caprine SIX3 gene. The associations of the goat POU1F1-PROP1-PITX1-SIX3 pathway genes polymorphisms and growth traits exhibited that these genes can be regarded as a genetic marker gene correlating with growth traits.

\section{Competing interests}

We certify that there is no conflict of interest with any financial organization regarding the material discussed in the manuscript.

\section{Acknowledgements}

This work was supported by the National Natural Science Foundation of China (No.31172184), Technology Foundation for Selected Overseas Chinese Schol- 
ar of Shaanxi Province (Lan XY, 2014-QD-14) and the National Project of Scientific Innovation Experiment for undergraduate of Northwest A\&F University (No.201510712097). We greatly thank the staff of the dairy goat breeding farm, Sanyuan country, Shaanxi province, P.R. China, the meat goat breeding farm, Zanzhou, Hainan province, P.R. China, for their collecting dairy goat samples and meat goat samples.

\section{References}

A h l aw at S., Sharma R., Maitra A., Tantia M.S. (2015). Current status of molecular genetics research of goat fecundity. Small Ruminant Res., 125: 34-42.

Ahmadi M.M., Mirzaei A., Sharifiyazdi H., Hajibemani A., Ghasrodashti A.R. (2015). Pituitary-specific transcription factor 1 (Pit-1) polymorphism and its association on milk production and some reproductive performance in Holstein dairy cows. Rev. Med. Vet., 166: $127-131$.

B a ş F., Uyguner Z.O., D arendeliler F., Aycan Z., Çetinkaya E., B erberoğlu M., Şiklar Z., Öcal G., Darcan Ş., Gökşen D., Topaloğlu A.K., Yüksel B., Özb e k M.N., Ercan O., Ev li y a ŏglu O., Ç et in k a y a S., Ş en Y., A t a b e k E., Toks oy G., Ay d i n B.K., B undak R. (2015). Molecular analysis of PROP1, POU1F1, LHX3, and HESX1 in Turkish patients with combined pituitary hormone deficiency: a multicenter study. Endocrine, 49: 479-491.

Castinetti F., Brinkmeier M.L., Gordon D.F., Vella K.R., Kerr J.M., Mortensen A.H., Hollenberg A., Brue T., Ridgway E.C., Camper S.A. (2011). PITX2 and PITX1 regulate thyrotroph function and response to hypothyroidism. Mol. Endocrinol., 25: 1950-1960.

Chang M.S., Han J.C., L e e J., Kwun Y., Huh R., Ki C.S., Ke e C., Cho S.Y., Jin D.K. (2015). A novel splice site mutation in the PAX6 gene in a Korean family with isolated aniridia. Ann. Clin. Lab. Sci., 45: 90-93.

Clark D.L., Clark D.I., B e ever J.E., Dilger A.C. (2015). Increased prenatal IGF2 expression due to the porcine intron3-G3072A mutation may be responsible for increased muscle mass. J. Anim. Sci., 93: 2546-2558.

Cohen L.E., Wond is ford F.E., Radovick S. (1997). Role of Pit-1 in the gene expression of growth hormone, prolactin, and thyrotropin. Endocrin. Metab. Clin., 25: 523-540.

D a g a C., P a lu d o M., L u ri d i a n a S., M u r a M.C., B o d a no S., P a z z o la M., D e t tori M.L., Vac c a G.M., Carcangiu V. (2013). Identification of novel SNPs in the Sarda breed goats POU1F1 gene and their association with milk productive performance. Mol. Biol. Rep., 40: 2829-2835.

E m i g h T.H. (1980). A comparison of tests for Hardy-Weinberg equilibrium. Biometrics, 36: 627-642.

F ang X.T., Xu H.X., Zhang C.L., Zhang J.M., L an X.Y., Gu C.W., Chen H. (2010). Polymorphisms in BMP-2 gene and their associations with growth traits in goats. Genes Genom., 32: 29-35.

F eng T., Chu M.X., C a o G.L., Tang Q.Q., Di R., F ang L., Li N. (2012). Polymorphisms of caprine POU1F1 gene and their association with litter size in Jining Grey goats. Mol. Biol. Rep., 39: 4029-4038.

H u a i Y.T., L a n X.Y., M a L., Wang J., L e i C.Z., Ch en H., Wang J.Q. (2011). Novel mutation in TGA stop-codon of bovine SIX6 gene. Mol. Biol., 45: 218-224.

Ja li l-Sarghale A., Shahrbabak M.M., Sharbabak H.M., Sadeghi M., Mura M.C. (2014). Association of pituitary specific transcription factor-1 (POU1F1) gene polymorphism with growth and biometric traits and blood metabolites in Iranian Zel and Lori-Bakhtiari sheep. Mol. Biol. Rep., 41: 5787-5792.

K i m G.W., Y o o J.Y., K i m H.Y. (2014). Association of genotype of POU1F1 intron 1 with carcass characteristics in crossbred pigs. J. Anim. Sci. Technol., 56: 25. 
Lan X.Y., Pan C.Y., Chen H., Le i C.Z., Hua L.S., Yang X.B., Qiu G.Y., Zhang R.F., L u n Y.Z. (2007 a). DdeI polymorphism in coding region of goat POU1F1 gene and its association with production traits. Asian Austral. J. Anim. Sci., 20: 1342-1348.

L a n X.Y., P a n C.Y., C h e n H., Z h a n g C.L., L i J.Y.,Z h a o M., L e i C.Z., Z h a n g A.L., Z h a ng L. (2007 b). An AluI PCR-RFLP detecting a silent allele at the goat POU1F1 locus and its association with production traits. Small Ruminant Res., 73: 8-12.

L a n X.Y., P an C.Y., Z h an g L.Z., Z h a o M., Z han g C.L., L e i C.Z., Ch en H. (2009 a). A novel missense (A79V) mutation of goat PROPl gene and its association with production traits. Mol. Biol. Rep., 36: 2069-2073.

L a n X.Y., Shu J.H., Ch en H., P an C.Y., L e i C.Z., Wang X., Li u S.Q., Z hang Y.B. (2009 b). A PstI polymorphism at 3'UTR of goat POU1F1 gene and its effect on cashmere production. Mol. Biol. Rep., 36: 1371-1374.

L a n X.Y., Hu a i Y.T., P an C.Y., Wang J., Huang Y.Z., Le i C.Z., Chen H. (2011). Novel genetic variants of sine oculis homeobox homolog 3 gene are associated with body weight and average daily gain in Bos taurus. Genes Genom., 33: 665-671.

L a n X.Y., Zh a o H.Y., L i Z.J., Z hou R., Ji a n g X.Y., H a n C.S., P a n C.Y., L e i C.Z., Chen H. (2013). Exploring novel genetic variant of PITX1 gene and its effect on milk performance in dairy goats. J. Integr. Agric., 12: 118-126.

L a z e a C., Gri g or e s c u - S i d o P., P o p p R., L e g e n d r e M.,A m s e l e m S., A l - K h z ou z C., Bucerzan S., Creţ V., Crişan M., Brad C. (2015). The c.301_302delAG PROP1 gene mutation in Romanian patients with multiple pituitary hormone deficiency. J. Pediatr. Endocr. Met., 28: 993-998.

Li S., Cren sh aw E.B., R a w s on E.J., S i m mon s D.M., S w a n s o n L.W., R o s e n fe ld M.G. (1990). Dwarf locus mutants lacking three pituitary cell types result from mutations in the POUdomain gene pit-1. Nature, 347: 528-533.

Liu Q.Y., Geng C.X., Chu M.X., Chen H.Q., Jin M., Zhang Y.J., Di R., F eng T., Li N. (2015). Polymorphism of Prophet of Pit-1 gene and its relationship with litter size of Small Tail Han sheep. J. Genet., 94: e27-e30.

Maitra A., Sharma R., Ahlawat S., Tantia M.S. (2014). Novel genetic polymorphisms in caprine GPR54 gene associated with reproductive functions. Indian J. Anim. Sci., 84: 1196-1201.

Mur a M.C., D a g a C., P a lu d o M., Luridi an a S., P a z zol a M., B od a no S., D e t tori M.L., Vac c a G.M., C a r c a n g i u V. (2012). Analysis of polymorphism within POU1F1 gene in relation to milk production traits in dairy Sarda sheep breed. Mol. Biol. Rep., 39: 6975-6979.

N e i M., R o y c h o u d h u ry A.K. (1974). Sampling variances of heterozygosity and genetic distance. Genetics, 76: 379-390.

Ozmen O., Kul S., Unal E.O. (2014). Polymorphism of sheep POU1F1 gene exon 6 and 3'UTR region and their association with milk production traits. Iranian J. Vet. Res., 15: 331-335.

Palagano E., Blair H.C., Pangrazio A., Tourkova I., Strina D., Angius A., Cuccuru G., Oppo M., Uva P., Van H.W., Boudin E., Superti-Furga A., Faletra F., Nocerino A., Ferrari M.C., Grappiolo G., Monari M., Montanelli A., Vezzon i P., Villa A., S o b a c ch i C. (2015). Buried in the middle but guilty: intronic mutations in the TCIRG1 gene cause human autosomal recessive osteopetrosis. J. Bone Miner. Res., 30: 1814-1821.

Pan C.Y., Wu C.Y., Ji a W.C., X u Y., Hu S.R., L e i C.Z., La n X.Y., Che n H. (2013). A critical functional missense mutation (H173R) in the bovine PROPl gene significantly affects growth traits in cattle. Gene, 531: 398-402.

Pfä ffle R., K l a m m t J. (2011). Pituitary transcription factors in the aetiology of combined pituitary hormone deficiency. Best Pract. Res. Cl. En., 25: 43-60.

P oulin G., Lebel M., Chamberland M., P a radis F.W., Drou in J. (2000). Specific protein-protein interaction between basic helix-loop-helix transcription factors and homeoproteins of the Pitx family. Mol. Cell. Biol., 20: 4826-4837.

Ribec a C., B onfatti V., C e c ch inat o A., A 1 bera A., Gallo L., Carni er P. (2014). Effect of polymorphisms in candidate genes on carcass and meat quality traits in double muscled Piemontese cattle. Meat Sci., 96: 1376-1383.

Sadeghi M., Jalil-Sarghale A., Moradi-Shahrbabak M. (2014). Associations of POU1F1 gene polymorphisms and protein structure changes with growth traits and blood metabolites in two Iranian sheep breeds. J. Genet., 93: 831-835. 
S a v a g e J.J., Ya de n B.C., K ir a ti pra n on P., R hod e s S.J. (2003). Transcriptional control during mammalian anterior pituitary development. Gene, 319: 1-19.

S e ong J., Oh J.D., Che ong I.C., L e e K.W., L e e H.K., S uh D.S., J e o n G.J., P ark K.D., K o n g H.S. (2011). Association between polymorphisms of Myf5 and POU1F1 genes with growth and carcass traits in Hanwoo (Korean cattle). Genes Genom., 33: 425-430.

S u n Y.J., L a n X.Y., L e i C.Z., Z h a n g C.L., C h e n H. (2015). Haplotype combination of the bovine CFL2 gene sequence variants and association with growth traits in Qinchuan cattle. Gene, 563: $136-141$.

Wang A.L., Z hang Y., Li M.J., L a n X.Y., Wang J.Q., Chen H. (2013). SNP identification in FBXO32 gene and their associations with growth traits in cattle. Gene, 515: 181-186.

Wang J., Li G.W., Elzo M.A., Yan L.J., Chen S.Y., J i a X.B., L a i S.J. (2015). A novel single nucleotide polymorphism of the $P O U 1 F 1$ gene associated with meat quality traits in rabbits. Ann. Anim. Sci., 15: 611-620.

X u T.S., L i u J.B., Ya o D.W., C a i H.F., Chen H., Zhou H.L., L a n X.Y. (2010). The prophet of PIT1 gene variation and its effect on growth traits in Chinese indigenous goat. J. Anim. Vet. Adv., 9: 2940-2946.

Yan L.J., F ang X.T., Liu Y., Zhang C.L., Li u X.X., Zhao J., Li J.J., Chen H. (2013). Effects of single and combined genotypes of MC4R and POU1F1 genes on two production traits in Langshan chicken. Mol. Biol. Rep., 40: 4645-4650.

Z eng X.C., Chen H.Y., J i a B., Z ha o Z.S., H u i W.Q., Wang Z.B., D u Y.C. (2011). Identification of SNPs within the sheep PROP1 gene and their effects on wool traits. Mol. Biol. Rep., 38: 2723-2728.

Zhang C.L., Liu B., Chen H., Lan X.Y., Le i C.Z., Zhang Z.Q., Zhang R.F. (2009). Associations of a HinfI PCR-RFLP of POU1F1 gene with growth traits in Qinchuan cattle. Anim. Biotechnol., 20: 71-74.

Zhang X.Y., Wu X.F., Ji a W.C., P an C.Y., Li X.C., Le i C.Z., Chen H., Lan X.Y. (2015). Novel nucleotide variations, haplotypes structure and associations with growth related traits of goat AT motif-binding factor (ATBF1) gene. Asian Austral. J. Anim. Sci., 28: 1394-1406.

Z h a o H.Y., W u X.F., C a i H.F., P a n C.Y., L e i C.Z., C h e n H., L a n X.Y. (2013). Genetic variants and effects on milk traits of the caprine paired-like homeodomain transcription factor 2 (PITX2) gene in dairy goats. Gene, 532: 203-210.

Zhou F.Y., Yang Q., Le i C.Z., Chen H., L a n X.Y. (2016). Relationship between genetic variants of POU1F1, PROP1, IGFBP3 genes and milk performance in Guanzhong dairy goats. Small Ruminant Res., 140: 40-45.

Received: 7 II 2016

Accepted: 11 X 2016 